\title{
Does socioeconomic level have an effect on school-age language skills in a developed country?
}

Ondene van Dulm and Frenette Southwood

Department of General Linguistics, Stellenbosch University, South Africa

E-mail: ondenevandulm@gmail.com; fs@sun.ac.za

\begin{abstract}
Socioeconomic status (SES) has been reported in several contexts as a predictor of child language skills. This study questions whether this holds true for New Zealand, a developed country in which government provides funding for additional academic support to low-SES schoolchildren. The language of 67 typically-developing, English-speaking 5- to 7-year-olds (40 high SES, 27 low SES) was assessed using two normed instruments (the Peabody Picture Vocabulary Test (Australian) (Dunn and Dunn 2007) and the Clinical Evaluation of Language Fundamentals (Australian) (Semel, Wiig and Secord 2006)) and one unnormed instrument (the Receptive and Expressive Activities for Language Therapy; Southwood and Van Dulm 2012). Although the low-SES group had significantly lower scores than the high-SES group on the two normed instruments, all participants' scores were within the expected age norms on these instruments. The low-SES group had significantly lower scores on the Receptive and Expressive Activities for Language Therapy for comprehension of articles, binding relations, passive constructions and $w h$ questions, and for production of passives and conjunctions. The language of young New Zealand schoolchildren thus appears similarly vulnerable to SES effects as those of children elsewhere. The question arises as to what can be done to allow these children to develop the language skills that will allow them to function optimally in the school context.
\end{abstract}

Keywords: socioeconomic status, later-developing language skills, New Zealand

\section{Introduction}

Socioeconomic status (SES) has been shown to be a predictor of language skills and executive functioning in children (Hoff 2003:1368; Hackman and Farah 2009:67-69). The language skills of young school-going children from lower-socioeconomic (SE) households are consistently found to lag behind those from mid-SE homes (e.g. Tough 1982:5-11; Walker, Greenwood, Hart and Carta 1994:617; Whitehurst 1997:246; Hoff 2003:1371-1372). Children from lowerSE households are often typically developing according to their community's expectations, but do not necessarily possess the language skills needed to engage fully in classroom discourse and to achieve success within the education system. 
Children from lower-SE households have been shown to possess restricted vocabularies compared to middle-class children (Arriaga, Fenson, Cronan and Pethick 1998; Feldman, Dollaghan, Campbell, Kurs-Lasky, Janosky and Paradise 2000; Raizada, Richards, Meltzoff and Kuhl 2008). This could be because parents from high-SE backgrounds tend (i) to use more and a greater variety of words than do parents from low-SE backgrounds, and (ii) to use these in longer sentences (cf. Hart and Risley 1992; also cf. Cartmill, Armstrong, Gleitman, GoldinMeadow, Medina and Trueswell 2013:11280).

In other language domains, children from low-SE backgrounds also appear to demonstrate less well-developed skills than their middle-class peers, and they acquire these skills more slowly (Hart and Risley 1995). These language-related differences between high- and low-SE children are partially attributed to differences in parental style and practices between SE groups. Mothers from low-SES backgrounds typically spend less time playing with and talking to their children (cf. Hoff-Ginsberg 1991). Children from low-SE households are thus involved in fewer social exchanges, which results in less extensive language exposure in their home environment. There are, however, not only quantitative but also qualitative differences between children from lower- and higher-SE households. For instance, mothers from higher-SES backgrounds tend to use a supportive interactional style in child-directed speech. This style is mostly non-directive in nature and less contingent on the child's speech and contains more questions asked for the purpose of eliciting conversation (Heath 1982, 1983; Hoff-Ginsberg 1991).

Studies in several countries have indicated the above-mentioned association between SES and language skills (also cf. Yeung, Linver and Brooks-Gunn 2002), with children from lower-SE backgrounds showing slower rates of development than their mid-SE peers. This begins in the second year of life and continues throughout the school-going years (Rescorla 1989; Arriaga et al. 1998; Rescorla and Alley 2001; Huttenlocher, Vasilyeva, Cymerman and Levine 2002). The question arose as to whether this is universally the case, and particularly whether it extends to the case of New Zealand. Very few New Zealand children do not attend a preschool facility (United Nations 2015a); and the New Zealand Ministry of Education deliberately provides additional funding to schools with a greater proportion of children from low-SE communities in an attempt to optimise the resources available for offering assistance to these children (New Zealand Ministry of Education 2015a). Resources allocated to schools in low-SE communities not also allocated to schools in higher-SE communities are "priority teacher supply allowance; national relocation grant; decile discretionary funding for principals; ... study support centres; [and] social workers in schools" (New Zealand Ministry of Education 2015b). It was thus expected that SES in this country with its high-income economy (The World Bank Group 2016) would have a limited impact on the language development of children, given the resources generally available to assist New Zealand children from low-SE backgrounds.

Limited research has thus far been published on the development of school-age language skills by New Zealand children. In one such study, a PhD study by Van Hees (2011), the vocabulary development and general oral language production of 12 case study participants (aged 5 years 2 months to 7 years 0 months) in Years 1 and 2 (viz. the equivalent of Grades R and 1 in South Africa) in four low-SE classrooms were assessed. The age equivalents of 10 of the participants with chronological ages of 5 years 3 months to 6 years 3 months were between 3 years 3 months and 6 years 0 months according to the British Picture Vocabulary Scale (Dunn, Dunn, Whetten and Burley 1997). One further participant scored close to the norm for their age, and one child scored above the norm (Van Hees 2011:61). The children's oral language production consisted 
of simple sentences and demonstrated limited vocabulary, and they did not express ideas in a logically-connected manner. In 11 of the 12 cases, the oral language production was far below that expected of children of this age (Van Hees n.d.:11). Van Hees (2011:ii) concludes that the vocabulary development and oral language skills of the participants were "highly constrained". There was no comparison of children across the SE range in the Van Hees (2011) study. The results of the study indicate that the language skills of New Zealand children from low-SE backgrounds are not ideal, but they do not indicate whether they are worse than those of children from more affluent backgrounds and, if so, how much worse.

The current study sets out to ascertain whether New Zealand children from low-SE backgrounds have less well-developed language skills than their higher-SE peers. It is important to ascertain the state of the language skills of New Zealand children from low-SE backgrounds because poorly-developed language skills place children at higher risk of academic failure and reading acquisition problems (cf. Aram and Nation 1980; Conti-Ramsden, Knox, Botting, and Simkin 2002; Klop and Tuomi 2007). Such problems can lead to restricted participation in those social and educational practices requiring advanced language skills and high levels of literacy.

\section{Research question}

The research question posed in the present study is: Do the receptive and expressive language skills of young school-aged children in New Zealand (a well-resourced developed country) vary according to SES? In order to answer this question, 5- to 7-year-old children from two SE backgrounds (mid- and low-) were compared in terms of their performance on a range of language measures, using a cross-sectional research design.

\section{Methodology}

\subsection{Procedures}

After obtaining ethical clearance from the Human Ethics Committee of Canterbury University and permission from the Christchurch office of the New Zealand Ministry of Education, a number of schools across the decile range (see section 3.2 below) were approached seeking permission to collect data among their students in Years 1 to 3 (viz. the equivalent of Grades $R$ to 2 in South Africa). One decile 10 and two decile 2 schools responded positively. Teachers of the Year 1 to 3 classes were requested to identify all children in their classes whose speech and language they regarded as typically-developing and who were performing as expected academically. Information documents and letters inviting participation in the study were distributed via the school among the caregivers of these children. In the absence of nonlanguage-related psychometric testing, this preselection by teachers acted as a screener to increase the likelihood of the obtained sample comprising children who represent the larger population. Teachers reported excluding students who presented with cerebral palsy, autism spectrum disorder, reading disorders, significant articulation problems, and clear and/or diagnosed language delays.

The parental consent rate per low-decile school was less than half that of the high-decile school. Selection bias cannot be ruled out and this should be borne in mind when the results are interpreted. Those children whose caregivers consented to participation and who reported them as typically developing in a questionnaire focusing on developmental, hearing, speech and 
language history underwent language testing. Two normed language assessments were administered to each participant to ensure that the children's language skills fell within normal limits. Those few children who obtained a score of more than one standard deviation below the norm for either or both of the assessments were excluded as possible participants. Their parents and classroom teachers were alerted to their low language scores and were encouraged to seek assistance in this regard. The remainder of the children acted as participants in the study. A series of unnormed assessments were administered to each participant individually during a series of 5 to 6 sessions of 20 to 30 minutes each over a period of 3 to 6 weeks. The participants' performance in these measures was compared across age and decile groups.

\subsection{Participants}

Monolingual English speakers (without other languages present in the home) aged 5 to 7 years participated in the study. All had (i) typical speech and language development according to a caregiver questionnaire; (ii) typical language abilities according to their teachers, who also judged them to fare academically as expected of a typically-developing child; and (iii) normal hearing and neurological function according to their teachers and the caregiver questionnaire. Their standard scores on two normed language assessment instruments were within one standard deviation below the respective norms. Note that we did not control for ethnicity as SES and not ethnicity was the independent variable in the study.

As stated above, participants were recruited from two low-decile schools (decile 2) and one high-decile school (decile 10), all in Christchurch. The decile reflects the New Zealand Ministry of Education's rating of the extent to which a school draws its students from low-SE communities. Decile 1 schools are those 10 percent of New Zealand schools which have the highest proportion of students from low-SE communities, and decile 10 schools are those 10 percent which have the lowest proportion. Deciles are calculated on the basis of five socioeconomic indicators, namely (i) the percentage of households with an income in the lowest $20 \%$ nationally; (ii) the percentage of employed parents in the lowest skill level occupational groups; (iii) the extent of household crowding; (iv) the percentage of parents with no educational qualifications; and (v) the percentage of parents receiving income support benefits (New Zealand Ministry of Education 2015b). The decile determines the amount of government funding allocated to a school, with the formula favoring low-decile schools in order to provide them with the additional resources required to adequately support children from low-SE households (New Zealand Ministry of Education 2015a). In this study, decile served as a proxy for SES. We acknowledge that many studies on the effects of SES on child development favor parental education level as a proxy for SES, and that school decile may be a less than ideal proxy, as it does not reliably indicate the overall socioeconomic make-up of a school's students (New Zealand Ministry of Education 2015a), nor does it necessarily accurately reflect the SES of any particular student. However, decile was used in the present study as the study was

conducted within the context of the New Zealand education system, which assigns a decile as a reflection of SES. Table 1 indicates the number of participants per age and decile. 
Table 1: Number of participants per age and decile

\begin{tabular}{|l|l|l|l|}
\hline \multirow{2}{*}{ Age } & \multicolumn{3}{|c|}{ Number of participants } \\
\cline { 2 - 4 } & In high-decile school & In low-decile schools & Total \\
\hline 5 years & 14 & 12 & 26 \\
\hline 6 years & 10 & 7 & 17 \\
\hline 7 years & 16 & 8 & 24 \\
\hline All ages combined & 40 & 27 & 67 \\
\hline
\end{tabular}

\subsection{Materials}

The Peabody Picture Vocabulary Test - Fourth Edition (Australian version) (PPVT-4; Dunn and Dunn 2007) and the four subtests of the Clinical Evaluation of Language Fundamentals Screening - Fourth Edition (Australian version) (CELF-4; Semel et al. 2006), namely Concepts and Following Directions, Word Structure, Recalling Sentences and Formulated Sentences, were administered.

Thereafter, five booklets of the Receptive and Expressive Activities for Language Therapy $(R E A L t)^{1}$ (Southwood and Van Dulm 2012) were administered. The REALt focuses on laterdeveloping language structures and skills. It was developed for use with children from 4 to 9 years of age who exhibit a language delay or disorder or who require deliberate exposure to certain language structures in their first or second language. While its primary purpose is to act as evidence-based language therapy material, the authors state that it can be used as a language assessment instrument (Southwood and Van Dulm 2012:1), as it was in the current study. The REALt consists of colour picture items with accompanying text, grouped into booklets according to the structures and skills targeted. This study utilised the booklets targeting the following: (i) comprehension and production of articles, (ii) comprehension and production of constructions containing binding relations, (iii) production of conjunctions, (iv) comprehension and production of passive constructions and (v) comprehension of wh questions. Each of the booklets has several subparts, briefly discussed below.

Two types of article use are targeted by the REALt, namely that to distinguish general from specific, and that to distinguish part from whole. Regarding the general vs. specific distinction, some REALt items focus on the child's knowledge that general $a$ becomes specific the once the entity has been introduced (cf. Roeper 2007:69-74), as in I saw a cat, but when I next looked, the cat was nowhere to be seen. Other items focus on the knowledge that if an entity is part of a larger whole, specific the is used for the entity once general $a$ has been used to introduce the whole (cf. Roeper 2007:74-76), as in When you get out of a car, you should close the door (not a door).

\footnotetext{
${ }^{1}$ It is not ideal to use an assessment instrument not standardised for and normed on the local population. We acknowledge that

(i) we used two instruments normed on Australian and not New Zealand populations. Considering the lack of other, more appropriate instruments, the PPVT-4 (Australian version) (Dunn and Dunn 2007) and the CELF-4 (Australian version) (Semel et al. 2006) are however regarded by child language professionals in New Zealand to be more appropriate than their American versions and are thus widely used by them.

(ii) the REALt was not developed with specifically the New Zealand child population in mind. The REALt was however trialled amongst New Zealand 4- to 8-year-olds and was subjectively judged by the administrators to be reasonably culturally appropriate for this population.
} 
The REALt items that target knowledge of binding relations are based on Principles A and $\mathrm{B}$ of Chomsky's (1981) Binding Theory. The latter states that a reflexive must be bound in its local domain (Binding Principle A) and a pronoun must be free (not bound) in its local domain (Binding Principle B). For example, in The man thought the boy accidentally hit himself, the reflexive himself must refer to the determiner phrase in its local domain, viz. the boy. By contrast, in The man thought the boy accidentally hit him, the personal pronoun him may not refer to the determiner phrase in its local domain (the boy). Him can refer either to the same person as the man or to a different male entity. The REALt targets the comprehension and production of constructions containing binding relations with both endophoric reference (as in The man thought the boy accidentally hit him, where him has the same referent as the man) and exophoric reference (where him does not share a referent with the man).

The REALt booklet on conjunctions contains items targeting production of seven earlierdeveloping conjunctions (if, because, before, until, after, while and since) and five laterdeveloping conjunctions (as soon as, whenever, although/even though, once and unless). Note that the comprehension of conjunctions is not targeted by the REALt.

The REALt targets the comprehension and production of three types of passive constructions:

(i) agentive or full passives, e.g. The car was washed by Mr Martin,

(ii) agentless or short passives, e.g. The car was washed, and

(iii) reversible passives, e.g. Pam was chased by Stevie and Stevie was chased by Pam.

The REALt contains several types of question constructions. For the purposes of this study, simple questions containing one wh element (such as Where did Alexander stay? or What did Mia eat?) were omitted. The focus was on the more complex question types covered by the $R E A L t$, of which there are three:

(i) conjoined questions, e.g. Where did Reuben go and how? Conjoined questions can be viewed as two questions in one (as opposed to the two full questions Where did Reuben go and How did he go there?) To answer such a question correctly, the listener must (i) recognise the syntactic dependencies (in this case, that Reuben is AGENT or EXPERIENCER, where the GOAL, and how the INSTRUMENT), and (ii) understand the elision of did he go there from the second question.

(ii) paired exhaustive questions, which require an exhaustive answer containing all pairs asked about (cf. Roeper 2007:178-181). For example, in answering Who ate the chocolate where?, one must state every eater as well as every place, e.g. Enya ate the chocolate in the tree house and Zoë ate it in bed.

(iii) barrier questions, in which certain syntactic elements act as barriers to the movement of a wh element (cf. Roeper 2004:43; Seymour, Roeper and de Villiers 2005:78-79). For instance, in Where did Kristin say what she ate?, what acts as a barrier to the movement of where, which could only have originated in the first clause (where Kristin said) and not in the second (*where Kristin ate).

\subsection{Statistical analyses}

A two-way ANOVA was calculated to test for differences in language test scores between the various age and decile groups separately and combined. A $p$-value of less than 0.05 was taken 
as indicating a significant difference. Given the small number of participants in each age band and the disproportionate numbers of participants from the low-decile schools and the highdecile school, the results of the statistical analyses should be interpreted with caution.

\section{Results}

\subsection{Normed measures: PPVT-4 and CELF-4}

On both normed language measures, the low-decile participants consistently obtained significantly lower scores than the high-decile participants $(F(1,61)=31.12 ; p<0.001$ for the PPVT-4; $F(1,61)=19.63 ; p<0.001$ for the CELF-4). This was expected, given the welldocumented poorer performance of children from low-SE backgrounds on standardised tests administered in formal test situations (cf. e.g. Duncan, Yeung, Brooks-Gunn and Smith 1998). No age-based differences were expected, as the relevant scores were standard scores, not raw scores. For the PPVT-4, there was indeed no age-based difference, whereas for the CELF-4, there was: $F(2,61)=3.49 ; p=0.036$. The 5 -year-old group achieved significantly higher average standard scores on the CELF-4 than did the other two age groups, whose scores did not differ significantly from each other. The reason for this age-based difference on the CELF-4 is not apparent. Note, however, that despite these decile-based and one age-based difference, all participants scored within the expected age norms on both the PPVT-4 and the CELF-4, as can be seen in Tables 2 and 3, respectively.

Table 2: $P P V T-4$ average standard scores, standard deviation and score range

\begin{tabular}{|c|c|c|c|c|c|}
\hline \multirow{2}{*}{\multicolumn{2}{|c|}{ Decile }} & \multicolumn{4}{|c|}{ Age } \\
\hline & & \multirow{2}{*}{$\begin{array}{r}5 \text { years } \\
14\end{array}$} & \multirow{2}{*}{$\begin{array}{r}6 \text { years } \\
10\end{array}$} & \multirow{2}{*}{$\begin{array}{r}7 \text { years } \\
16\end{array}$} & \multirow{2}{*}{$\begin{array}{c}\text { All ages } \\
\text { combined } \\
40\end{array}$} \\
\hline \multirow{4}{*}{$\begin{array}{l}\text { High } \\
\text { decile }\end{array}$} & Number of participants & & & & \\
\hline & Mean score & 112.21 & 120.00 & 108.44 & 112.65 \\
\hline & Standard deviation & 12.70 & 10.71 & 11.34 & 12.29 \\
\hline & Range & $94-144$ & $100-132$ & $85-127$ & $85-144$ \\
\hline \multirow{4}{*}{$\begin{array}{l}\text { Low } \\
\text { decile }\end{array}$} & Number of participants & 12 & 7 & 8 & 27 \\
\hline & Mean score & 103.25 & 97.43 & 95.25 & 99.37 \\
\hline & Standard deviation & 8.64 & 7.48 & 8.31 & 8.73 \\
\hline & Range & $88-117$ & $88-106$ & $89-113$ & $88-117$ \\
\hline \multirow{4}{*}{$\begin{array}{l}\text { Combined } \\
\text { deciles }\end{array}$} & Number of participants & 26 & 17 & 24 & 67 \\
\hline & Mean score & 108.08 & 110.71 & 104.04 & \\
\hline & Standard deviation & 11.73 & 14.72 & 12.05 & \\
\hline & Range & $88-144$ & $88-132$ & $85-127$ & \\
\hline
\end{tabular}


Table 3: $C E L F-4$ average standard scores, standard deviation and score range

\begin{tabular}{|c|c|c|c|c|c|}
\hline \multirow{2}{*}{\multicolumn{2}{|c|}{ Decile }} & \multicolumn{4}{|c|}{ Age } \\
\hline & & \multirow{2}{*}{$\begin{array}{r}5 \text { years } \\
14\end{array}$} & \multirow{2}{*}{$\begin{array}{r}6 \text { years } \\
10\end{array}$} & \multirow{2}{*}{$\begin{array}{r}7 \text { years } \\
16\end{array}$} & \multirow{2}{*}{$\begin{array}{c}\begin{array}{c}\text { All ages } \\
\text { combined }\end{array} \\
\end{array}$} \\
\hline \multirow{4}{*}{$\begin{array}{l}\text { High } \\
\text { decile }\end{array}$} & Number of participants & & & & \\
\hline & Mean score & 111.36 & 103.60 & 104.50 & 106.68 \\
\hline & Standard deviation & 8.63 & 13.25 & 8.96 & 10.42 \\
\hline & Range & $99-125$ & $85-128$ & $89-122$ & $85-128$ \\
\hline \multirow{4}{*}{$\begin{array}{l}\text { Low } \\
\text { decile }\end{array}$} & Number of participants & 12 & 7 & 8 & 27 \\
\hline & Mean score & 99.42 & 95.71 & 93.38 & 96.67 \\
\hline & Standard deviation & 6.86 & 8.44 & 7.46 & 7.64 \\
\hline & Range & $87-113$ & $85-108$ & $85-106$ & $85-113$ \\
\hline \multirow{4}{*}{$\begin{array}{l}\text { Combined } \\
\text { deciles }\end{array}$} & Number of participants & 26 & 17 & 24 & 67 \\
\hline & Mean score & 105.85 & 100.35 & 100.79 & \\
\hline & Standard deviation & 9.81 & 11.90 & 9.90 & \\
\hline & Range & $87-125$ & $85-128$ & $85-122$ & \\
\hline
\end{tabular}

\subsection{Unnormed measures: $R E A L t$}

In terms of the total score for each of the structures assessed by the REALt booklets, the lowdecile participants consistently obtained significantly lower scores than did the high-decile participants. Table 4 provides a summary of these total scores. Below the table, the performance of each group on each structure is discussed in turn, presenting separate scores for the various types and subtypes of items within each structure. Relevant raw scores, $F$-values and $p$-values are presented in table format, after which percentage scores are plotted in graph format, per age group. Thereafter, a summarising table is presented indicating decile differences per age. 
Table 4: Average participant scores on REALt measures

\begin{tabular}{|c|c|c|c|c|c|c|c|c|c|}
\hline \multirow{2}{*}{$\begin{array}{l}\text { Measure } \\
\text { (number of } \\
\text { items in } \\
\text { parentheses) }{ }^{\mathrm{a}}\end{array}$} & \multicolumn{3}{|c|}{ High decile $(n=40)$} & \multicolumn{3}{|c|}{ Low decile $(n=27)$} & \multirow{2}{*}{$\begin{array}{c}F \\
(1,61)\end{array}$} & \multirow[t]{2}{*}{$p$} & \multirow[t]{2}{*}{ Direction } \\
\hline & Mean & $\mathbf{S D}^{\mathbf{b}}$ & Range & Mean & $\mathbf{S D}^{\mathbf{b}}$ & Range & & & \\
\hline $\begin{array}{l}\text { Articles } \\
(30)\end{array}$ & $\begin{array}{l}23.48^{\mathrm{c}} \\
(78 \%)\end{array}$ & 3.29 & $\begin{array}{c}15-29 \\
(50- \\
97 \%)\end{array}$ & $\begin{array}{l}20.74 \\
(69 \%)\end{array}$ & 3.76 & $\begin{array}{c}10-26 \\
(33- \\
87 \%)\end{array}$ & 9.98 & 0.003 & $\mathrm{HD}>\mathrm{LD}^{\mathrm{d}}$ \\
\hline $\begin{array}{l}\text { Binding } \\
(22)\end{array}$ & $\begin{array}{r}16.40 \\
(75 \%)\end{array}$ & 2.09 & $\begin{array}{c}11-20 \\
(50- \\
91 \%)\end{array}$ & $\begin{array}{r}14.59 \\
(66 \%)\end{array}$ & 2.62 & $\begin{array}{c}11-20 \\
(50- \\
91 \%)\end{array}$ & 8.00 & 0.006 & $\mathrm{HD}>\mathrm{LD}$ \\
\hline $\begin{array}{l}\text { Conjunctions } \\
\text { (19) }\end{array}$ & $\begin{array}{l}11.25 \\
(59 \%)\end{array}$ & 2.37 & $\begin{array}{l}5-15 \\
(26- \\
79 \%)\end{array}$ & $\begin{array}{r}8.26 \\
(43 \%)\end{array}$ & 2.46 & $\begin{array}{l}3-13 \\
(16- \\
68 \%)\end{array}$ & 3.73 & $<0.001$ & $\begin{array}{l}\mathrm{HD}>\mathrm{LD} \\
\text { at } 5 \text { yrs; } \\
\mathrm{HD}=\mathrm{LD} \\
\text { at } 6 \text { and } 7 \\
\text { yrs }\end{array}$ \\
\hline $\begin{array}{l}\text { Passives } \\
\text { (60) }\end{array}$ & $\begin{array}{r}51.45 \\
(86 \%)\end{array}$ & 4.88 & $\begin{array}{c}40-59 \\
(67- \\
98 \%)\end{array}$ & $\begin{array}{r}43.07 \\
(72 \%)\end{array}$ & 6.83 & $\begin{array}{c}28-57 \\
(47- \\
95 \%)\end{array}$ & 35.80 & 0.000 & $\mathrm{HD}>\mathrm{LD}$ \\
\hline $\begin{array}{l}\text { Wh questions } \\
\text { (29) }\end{array}$ & $\begin{array}{r}24.28 \\
(84 \%)\end{array}$ & 2.98 & $\begin{array}{c}17-29 \\
(58- \\
100 \%) \\
\end{array}$ & $\begin{array}{r}21.00 \\
(72 \%)\end{array}$ & 4.07 & $\begin{array}{c}8-26 \\
(28- \\
90 \%)\end{array}$ & 11.76 & 0.001 & $\mathrm{HD}>\mathrm{LD}$ \\
\hline
\end{tabular}

Table notes: ${ }^{\text {a }}$ The number of items is also the maximum obtainable score. ${ }^{\mathrm{b}} \mathrm{SD}=$ standard deviation. ${ }^{\mathrm{C}}$ Scores are presented as raw scores with percentages in parentheses for the mean and the range. ${ }^{\mathrm{d}} \mathrm{HD}=$ high-decile group; $\mathrm{LD}=$ low-decile group.

\subsubsection{Articles}

Both comprehension and production of the general vs. specific use of articles were assessed. Comprehension was found to differ significantly between the two decile groups. The highdecile group had significantly higher scores than the low-decile group at 5 and 6 years of age, but there was no statistically significant difference at 7 years of age. For the production of general vs. specific articles, there was also a significant difference between the decile groups. Performance did not differ significantly at age 5 and 6 years, but at 7 years the low-decile group had significantly lower scores than the high-decile group.

Only production of the part vs. whole use of articles was assessed. (A picture-based task does not lend itself to testing comprehension of part vs. whole use.) The differences between the decile groups were not significant, but the high-decile group obtained higher scores than the low-decile group. See Table 5 and Figure 1. 
Table 5: Average participant scores on article comprehension and production tasks of the REALt

\begin{tabular}{|c|c|c|c|c|c|c|c|c|}
\hline \multirow{2}{*}{$\begin{array}{l}\text { Measure } \\
\text { (number of items in } \\
\text { parentheses) }^{\mathrm{a}}\end{array}$} & \multicolumn{3}{|c|}{ High decile $(n=40)$} & \multicolumn{3}{|c|}{ Low decile $(n=27)$} & \multirow{2}{*}{$\begin{array}{c}F \\
(1,61)\end{array}$} & \multirow[t]{2}{*}{$p$} \\
\hline & Mean & bSD & Range & Mean & ${ }^{b S D}$ & Range & & \\
\hline $\begin{array}{l}\text { Comprehension: } \\
\text { general-specific (10) }\end{array}$ & $\begin{array}{r}8.68^{\mathrm{c}} \\
(87 \%)\end{array}$ & 1.21 & $\begin{array}{c}5-10 \\
(50- \\
100 \%)\end{array}$ & $\begin{array}{r}7.70 \\
(77 \%)\end{array}$ & 1.75 & $\begin{array}{c}3-10 \\
(30- \\
100 \%)\end{array}$ & 7.50 & 0.008 \\
\hline $\begin{array}{l}\text { Production: } \\
\text { general-specific (10) }\end{array}$ & $\begin{array}{r}6.45 \\
(65 \%)\end{array}$ & 1.69 & $\begin{array}{c}3-10 \\
(30- \\
100 \%)\end{array}$ & $\begin{array}{r}5.56 \\
(56 \%)\end{array}$ & 1.58 & $\begin{array}{c}2-9 \\
(20- \\
90 \%)\end{array}$ & 4.81 & 0.032 \\
\hline $\begin{array}{l}\text { Production: part-whole } \\
\text { (10) }\end{array}$ & $\begin{array}{r}8.35 \\
(84 \%)\end{array}$ & 1.69 & $\begin{array}{c}3-10 \\
(30- \\
100 \%)\end{array}$ & $\begin{array}{r}7.48 \\
(75 \%)\end{array}$ & 1.67 & $\begin{array}{c}3-10 \\
(30- \\
100 \%)\end{array}$ & 3.66 & 0.060 \\
\hline $\begin{array}{l}\text { Total production score } \\
\text { (20) }\end{array}$ & $\begin{array}{r}14.80 \\
(74 \%)\end{array}$ & 2.94 & $\begin{array}{c}10-20 \\
(50- \\
100 \%)\end{array}$ & $\begin{array}{l}13.04 \\
(65 \%)\end{array}$ & 2.72 & $\begin{array}{l}6-17 \\
(30- \\
85 \%)\end{array}$ & 6.12 & 0.016 \\
\hline
\end{tabular}

Table notes: ${ }^{a}$ The number of items is also the maximum obtainable score. ${ }^{\mathrm{b}} \mathrm{SD}=$ standard deviation. ${ }^{\mathrm{c}}$ Scores are presented as raw scores with percentages in parentheses for the mean and the range.

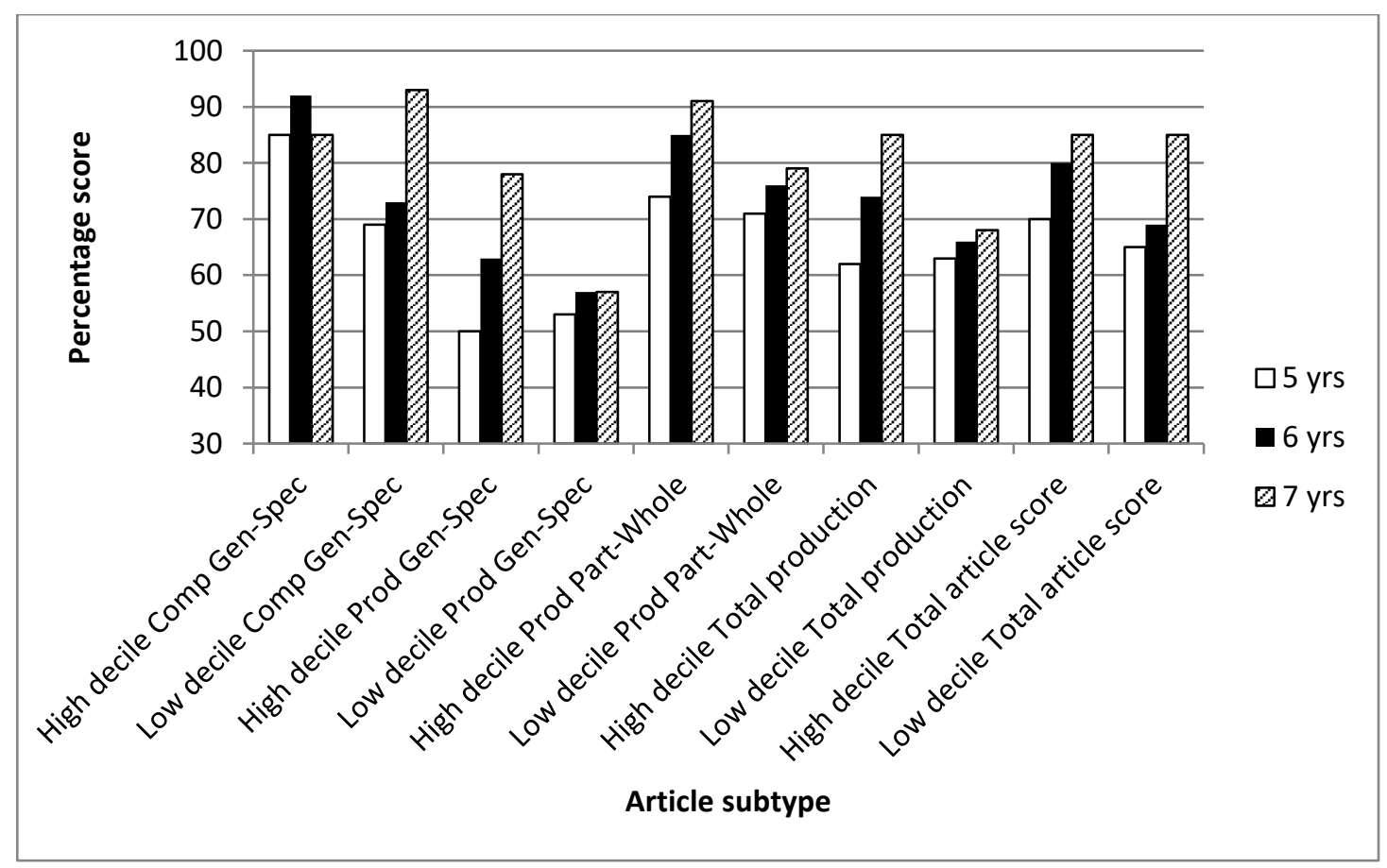

Figure 1: Average percentage scores for article comprehension and production

\subsubsection{Constructions containing binding relations}

For the binding comprehension items, there was a significant difference between the two decile groups, with the high-decile group obtaining higher scores than the low-decile group. The 
difference between scores on the production tasks was not significant, but the high-decile group obtained the higher scores. See Table 6 and Figure 2.

Table 6: Average participant scores on binding relations tasks of the REALt

\begin{tabular}{|c|c|c|c|c|c|c|c|c|}
\hline \multirow{2}{*}{$\begin{array}{l}\text { Measure } \\
\text { (number of items in } \\
\text { parentheses) })^{\mathrm{a}}\end{array}$} & \multicolumn{3}{|c|}{ High decile $(n=40)$} & \multicolumn{3}{|c|}{ Low decile $(n=27)$} & \multirow{2}{*}{$\begin{array}{c}F \\
(\mathbf{1 , 6 1 )}\end{array}$} & \multirow[t]{2}{*}{$p$} \\
\hline & Mean & $\mathbf{S D}^{\mathbf{b}}$ & Range & Mean & SD & Range & & \\
\hline $\begin{array}{l}\text { Comprehension } \\
\text { (12) }\end{array}$ & $\begin{array}{r}9.43^{\mathrm{c}} \\
(79 \%)\end{array}$ & 1.26 & $\begin{array}{c}7-12 \\
(58- \\
100 \%) \\
\end{array}$ & $\begin{array}{r}8.67 \\
(72 \%)\end{array}$ & 1.14 & $\begin{array}{c}7-12 \\
(58- \\
100 \%) \\
\end{array}$ & 5.33 & 0.024 \\
\hline $\begin{array}{l}\text { Production } \\
\text { (10) }\end{array}$ & $\begin{array}{r}6.98 \\
(70 \%)\end{array}$ & 1.73 & $\begin{array}{c}2-10 \\
(20- \\
100 \%)\end{array}$ & $\begin{array}{r}5.93 \\
(59 \%)\end{array}$ & 2.18 & $\begin{array}{c}2-10 \\
(20- \\
100 \%)\end{array}$ & 3.98 & 0.051 \\
\hline
\end{tabular}

Table notes: ${ }^{a}$ The number of items is also the maximum obtainable score. ${ }^{\mathrm{b}} \mathrm{SD}=$ standard deviation. ${ }^{\mathrm{c}}$ Scores are presented as raw scores with percentages in parentheses for the mean and the range.

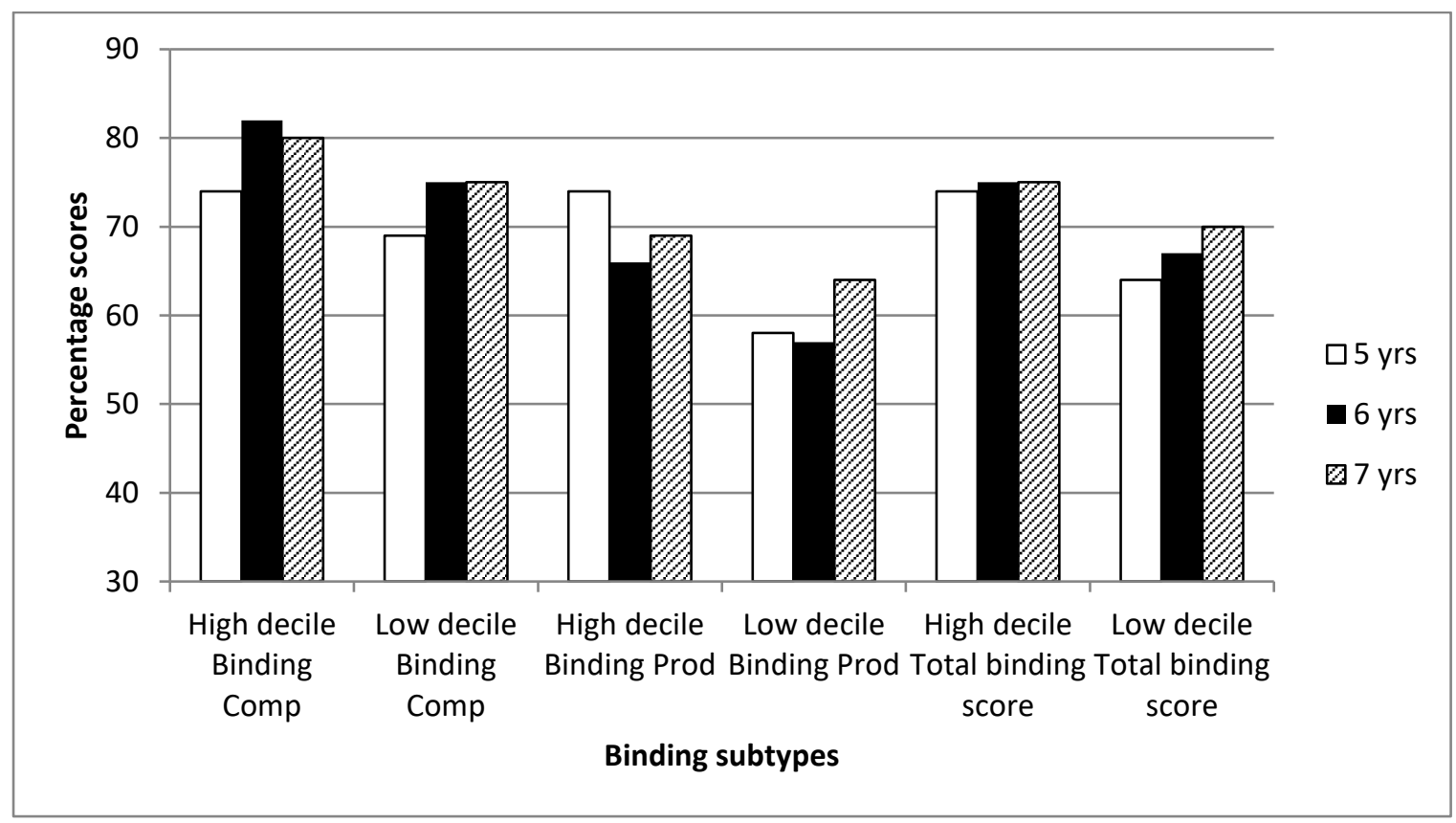

Figure 2: Average percentage scores for binding comprehension and production

\subsubsection{Conjunctions}

In the production tasks for both earlier- and later-developing conjunctions, the high-decile group obtained significantly higher scores than did the low-decile group. For earlier-developing conjunctions, however, this was only the case among the 5-year-olds. From 6 years onward, the low-decile participants scored on par with the high-decile participants. For later-developing conjunctions, the scores of the high-decile group were significantly higher across all age groups. 
As stated above and indicated in Table 4, the total conjunction scores (production of earlierand later-developing conjunctions combined) differed significantly between the two decile groups. The scores of the low-decile group were significantly lower than those of their highdecile peers at ages 5 and 7 years. At age 6 years, there was no significant difference between the two decile groups. The reason for this particular difference in trajectory between decile groups is not apparent. See Table 7 and Figure 3.

Table 7: Average participant scores on conjunction production tasks of the REALt

\begin{tabular}{|c|c|c|c|c|c|c|c|c|}
\hline \multirow{2}{*}{$\begin{array}{l}\text { Measure } \\
\text { (number of items in } \\
\text { parentheses) }^{\mathrm{a}}\end{array}$} & \multicolumn{3}{|c|}{ High decile $(n=40)$} & \multicolumn{3}{|c|}{ Low decile $(n=27)$} & \multirow{2}{*}{$\begin{array}{c}F \\
(\mathbf{1 , 6 1})\end{array}$} & \multirow[t]{2}{*}{$P$} \\
\hline & Mean & $\mathbf{S D}^{\mathbf{b}}$ & Range & Mean & SD & Range & & \\
\hline $\begin{array}{l}\text { Earlier-developing } \\
\text { (14) }\end{array}$ & $\begin{array}{r}7.60 \\
(54 \%)\end{array}$ & 1.86 & $\begin{array}{c}3-11 \\
(21- \\
79 \%)\end{array}$ & $\begin{array}{r}5.93 \\
(42 \%)\end{array}$ & 1.80 & $\begin{array}{l}2-10 \\
(14- \\
71 \%)\end{array}$ & 9.32 & 0.003 \\
\hline $\begin{array}{l}\text { Later-developing } \\
\text { (5) }\end{array}$ & $\begin{array}{r}3.65 \\
(73 \%)\end{array}$ & 1.05 & $\begin{array}{c}1-5 \\
(20- \\
100 \%)\end{array}$ & $\begin{array}{r}2.33 \\
(47 \%)\end{array}$ & 1.27 & $\begin{array}{c}1-5 \\
(20- \\
100 \%)\end{array}$ & 17.44 & $<0.001$ \\
\hline
\end{tabular}

Table notes: ${ }^{a}$ The number of items is also the maximum obtainable score. ${ }^{\mathrm{b}} \mathrm{SD}=$ standard deviation. ${ }^{\mathrm{c}}$ Scores are presented as raw scores with percentages in parentheses for the mean and the range.

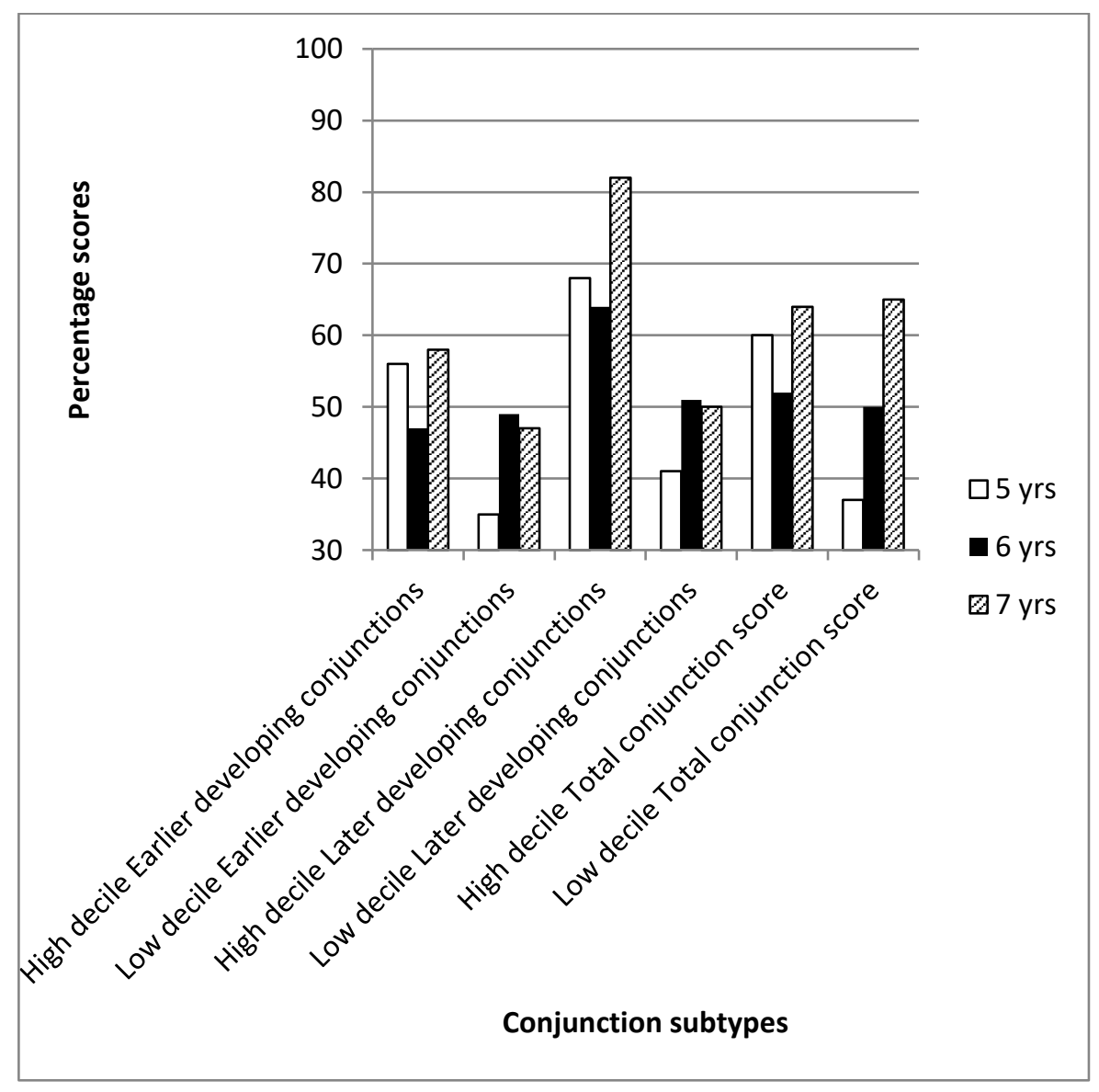

Figure 3: Average percentage scores for conjunction production 


\subsubsection{Passive constructions}

In terms of comprehension, there was a significant difference between the two decile groups for reversible passives (with the high-decile group obtaining higher scores than the low-decile group), but not for agentive and agentless passive constructions. When collapsing the scores for the three comprehension tasks, the high- and low-decile groups did differ significantly, with the former outperforming the latter.

With regard to production of passive constructions, the difference between the two groups was significant for agentive and agentless passives as well as for reversible passives, with the scores of the high-decile group being higher than those of the low-decile group. See Table 8 and Figure 4.

Table 8: Average participant scores on passive comprehension and production tasks of the REALt

\begin{tabular}{|c|c|c|c|c|c|c|c|c|}
\hline \multirow{2}{*}{$\begin{array}{l}\text { Measure } \\
\text { (number of items in } \\
\text { parentheses) }{ }^{\mathrm{a}}\end{array}$} & \multicolumn{3}{|c|}{ High decile $(n=40)$} & \multicolumn{3}{|c|}{ Low decile $(n=27)$} & \multirow{2}{*}{$\begin{array}{c}F \\
(1,61)\end{array}$} & \multirow[t]{2}{*}{$\boldsymbol{P}$} \\
\hline & Mean & SD $^{\mathbf{b}}$ & Range & Mean & SD & Range & & \\
\hline $\begin{array}{l}\text { Comprehension: } \\
\text { reversible } \\
\text { (15) }\end{array}$ & $\begin{array}{r}12.75 \\
(85 \%)\end{array}$ & 1.79 & $\begin{array}{c}8-15 \\
(53- \\
100 \%)\end{array}$ & $\begin{array}{l}10.78 \\
(72 \%)\end{array}$ & 2.01 & $\begin{array}{c}7-14 \\
(47- \\
93 \%)\end{array}$ & 16.09 & $<0.001$ \\
\hline $\begin{array}{l}\text { Comprehension: } \\
\text { agentless } \\
\text { (10) }\end{array}$ & $\begin{array}{r}9.35 \\
(94 \%)\end{array}$ & 0.89 & $\begin{array}{c}6-10 \\
(60- \\
100 \%)\end{array}$ & $\begin{array}{r}8.85 \\
(89 \%)\end{array}$ & 1.06 & $\begin{array}{c}7-10 \\
(70- \\
100 \%)\end{array}$ & 3.84 & 0.055 \\
\hline $\begin{array}{l}\text { Comprehension: } \\
\text { agentive } \\
\text { (10) }\end{array}$ & $\begin{array}{r}9.55 \\
(96 \%)\end{array}$ & 0.64 & $\begin{array}{c}8-10 \\
(80- \\
100 \%)\end{array}$ & $\begin{array}{r}9.15 \\
(90 \%)\end{array}$ & 1.03 & $\begin{array}{c}7-10 \\
(70- \\
100 \%)\end{array}$ & 2.66 & 0.108 \\
\hline $\begin{array}{l}\text { Total comprehension } \\
\text { score } \\
(35)\end{array}$ & $\begin{array}{l}31.65 \\
(90 \%)\end{array}$ & 2.54 & $\begin{array}{c}25-35 \\
(71- \\
100 \%)\end{array}$ & $\begin{array}{l}28.78 \\
(82 \%)\end{array}$ & 2.90 & $\begin{array}{c}22-34 \\
(63- \\
97 \%)\end{array}$ & 17.18 & $<0.001$ \\
\hline $\begin{array}{l}\text { Production: reversible } \\
\text { (15) }\end{array}$ & $\begin{array}{l}11.35 \\
(76 \%)\end{array}$ & 2.07 & $\begin{array}{c}6-15 \\
(40- \\
100 \%)\end{array}$ & $\begin{array}{r}8.00 \\
(53 \%)\end{array}$ & 3.10 & $\begin{array}{c}1-13 \\
(7- \\
87 \%)\end{array}$ & 26.42 & $<0.001$ \\
\hline $\begin{array}{l}\text { Production: agentive } \\
\text { and agentless } \\
\text { (10) }\end{array}$ & $\begin{array}{r}8.45 \\
(85 \%)\end{array}$ & 1.48 & $\begin{array}{c}4-10 \\
(40- \\
100 \%)\end{array}$ & $\begin{array}{r}6.30 \\
(63 \%)\end{array}$ & 2.57 & $\begin{array}{c}2-10 \\
(20- \\
100 \%)\end{array}$ & 15.21 & $<0.001$ \\
\hline $\begin{array}{l}\text { Total production score } \\
\text { (25) }\end{array}$ & $\begin{array}{r}19.80 \\
(79 \%)\end{array}$ & 3.11 & $\begin{array}{c}15-25 \\
(60- \\
100 \%)\end{array}$ & $\begin{array}{r}14.29 \\
(57 \%)\end{array}$ & 5.09 & $\begin{array}{l}3-23 \\
(12- \\
92 \%)\end{array}$ & 28.24 & $<0.001$ \\
\hline
\end{tabular}

Table notes: ${ }^{a}$ The number of items is also the maximum obtainable score. ${ }^{\mathrm{b}} \mathrm{SD}=$ standard deviation. ${ }^{\mathrm{c}}$ Scores are presented as raw scores with percentages in parentheses for the mean and the range. 


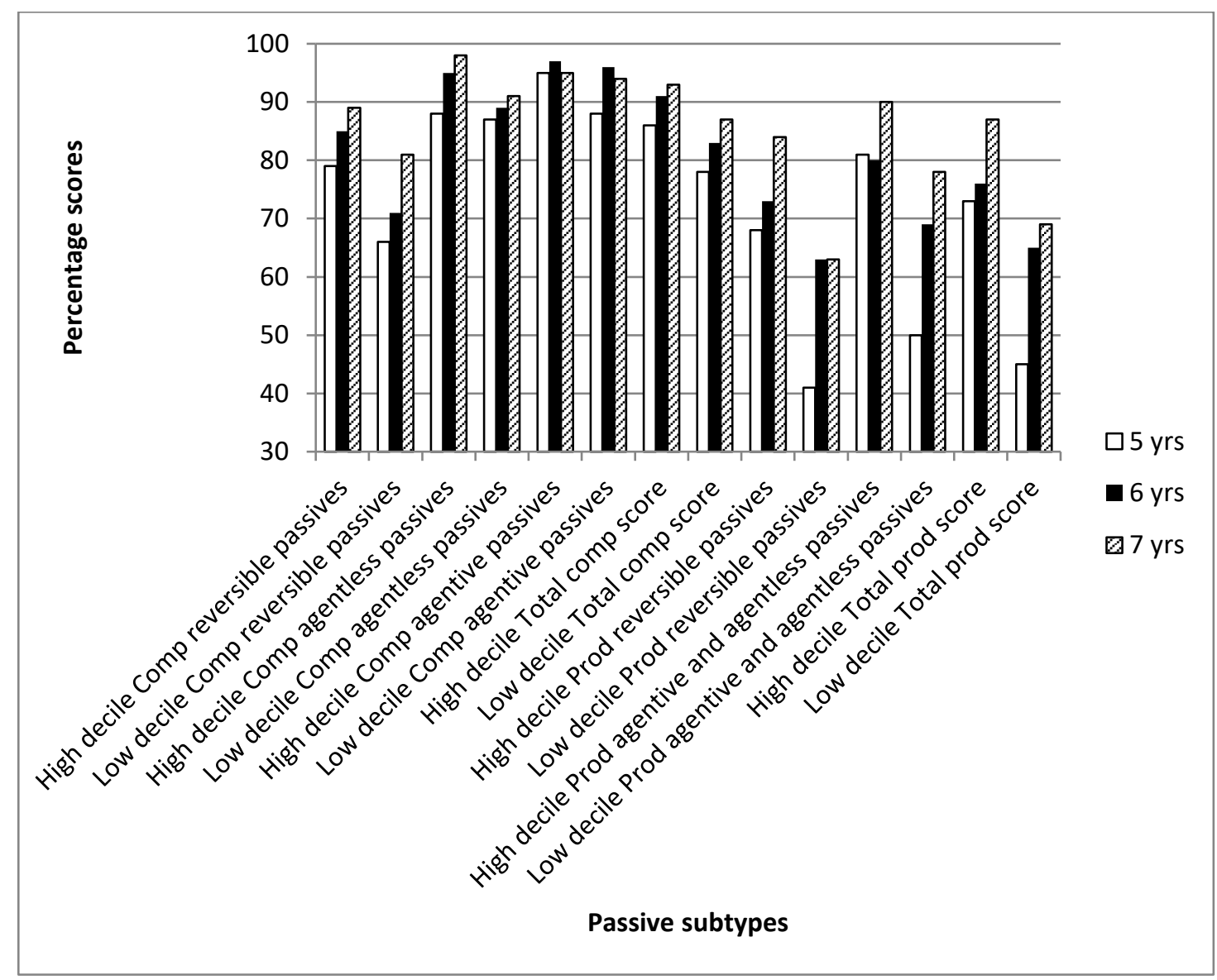

Figure 4: Average percentage scores for passive comprehension and production

\subsubsection{Wh question constructions}

For the comprehension of each of the complex question types, there was a significant difference between the scores of the two decile groups, with the high-decile group obtaining higher scores than the low-decile group across all ages. See Table 9 and Figure 5. 
Table 9: Average participant scores on wh question comprehension tasks of the REALt

\begin{tabular}{|c|c|c|c|c|c|c|c|c|}
\hline \multirow{2}{*}{$\begin{array}{l}\text { Measure } \\
\text { (number of items in } \\
\text { parentheses) }^{\mathrm{a}}\end{array}$} & \multicolumn{3}{|c|}{ High decile $(n=40)$} & \multicolumn{3}{|c|}{ Low decile $(n=27)$} & \multirow{2}{*}{$\begin{array}{c}F \\
(\mathbf{1 , 6 1 )}\end{array}$} & \multirow[t]{2}{*}{$P$} \\
\hline & Mean & $\mathbf{S D}^{\mathbf{b}}$ & Range & Mean & SD & Range & & \\
\hline $\begin{array}{l}\text { Conjoined } \\
\text { (5) }\end{array}$ & $\begin{array}{r}4.45 \\
(89 \%)\end{array}$ & 0.68 & $\begin{array}{c}3-5 \\
(60- \\
100 \%)\end{array}$ & $\begin{array}{r}3.89 \\
(78 \%)\end{array}$ & 1.09 & $\begin{array}{c}0-5 \\
(0- \\
100 \%)\end{array}$ & 4.48 & 0.038 \\
\hline $\begin{array}{l}\text { Paired exhaustive } \\
\text { (12) }\end{array}$ & $\begin{array}{r}9.53 \\
(79 \%)\end{array}$ & 1.24 & $\begin{array}{c}7-12 \\
(58- \\
100 \%)\end{array}$ & $\begin{array}{r}8.15 \\
(68 \%)\end{array}$ & 2.21 & $\begin{array}{l}3-11 \\
(25- \\
92 \%)\end{array}$ & 9.73 & 0.003 \\
\hline $\begin{array}{l}\text { Barrier } \\
(12)\end{array}$ & $\begin{array}{r}10.30 \\
(86 \%)\end{array}$ & 8.96 & $\begin{array}{c}6-12 \\
(50- \\
100 \%)\end{array}$ & $\begin{array}{r}8.96 \\
(75 \%)\end{array}$ & 1.60 & $\begin{array}{l}5-11 \\
(42- \\
92 \%)\end{array}$ & 8.43 & 0.005 \\
\hline
\end{tabular}

Table notes: ${ }^{a}$ The number of items is also the maximum obtainable score. ${ }^{\mathrm{b}} \mathrm{SD}=$ standard deviation. ${ }^{\mathrm{C}}$ Scores are presented as raw scores with percentages in parentheses for the mean and the range.

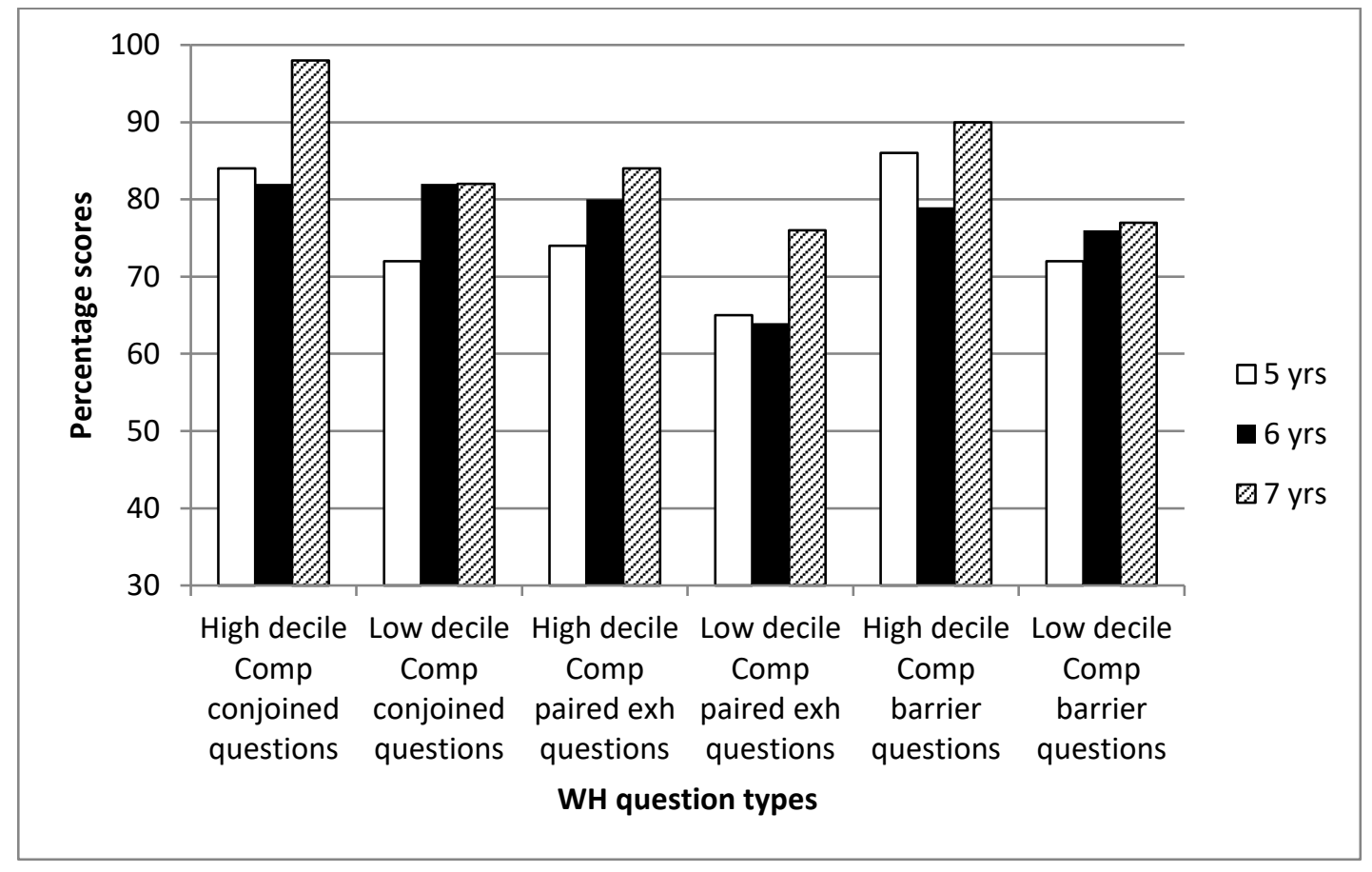

Figure 5: Average percentage scores for wh question production

\subsection{Summary of decile differences per age}

Table 10 presents the differences between the two decile groups per age. Specifically, it indicates at which ages the differences in scores between the two decile groups are significant. In all instances in which the differences are indeed significant, the high-decile group obtained the higher score. 
Table 10: Significant decile group differences on each measure, per age group

\begin{tabular}{|c|c|c|c|}
\hline \multirow[t]{2}{*}{ Measure } & \multicolumn{3}{|c|}{$\begin{array}{l}\text { Is there a significant difference between } \\
\text { decile groups? } \\
\sqrt{ }=\text { yes; } x=\text { no }\end{array}$} \\
\hline & At 5 years & At 6 years & At 7 years \\
\hline$P P V T-4$ & $\sqrt{ }$ & $\sqrt{1}$ & $\sqrt{ }$ \\
\hline CELF-4 & $\sqrt{ }$ & $\sqrt{ }$ & $\sqrt{ }$ \\
\hline ARTICLES: total score & $\sqrt{ }$ & $\sqrt{ }$ & $\sqrt{ }$ \\
\hline Article comprehension: general-specific & $\sqrt{ }$ & $\sqrt{ }$ & $\mathrm{x}$ \\
\hline Article production: general-specific & $\mathrm{x}$ & $\mathrm{x}$ & $\mathrm{x}$ \\
\hline Article production: part-whole & $\mathrm{x}$ & $\mathrm{x}$ & $\mathrm{x}$ \\
\hline Total article production score & $\mathrm{x}$ & $\mathrm{x}$ & $\sqrt{ }$ \\
\hline BINDING: total score & $\sqrt{ }$ & $\sqrt{ }$ & $\sqrt{ }$ \\
\hline Binding comprehension & $\sqrt{ }$ & $\sqrt{ }$ & $\sqrt{ }$ \\
\hline Binding production & $\mathrm{x}$ & $\mathrm{x}$ & $\mathrm{X}$ \\
\hline CONJUNCTIONS: total score & $\sqrt{ }$ & $\mathrm{x}$ & $\sqrt{ }$ \\
\hline $\begin{array}{l}\text { Conjunction production: earlier-developing } \\
\text { conjunctions }\end{array}$ & $\sqrt{ }$ & $\mathrm{x}$ & $\mathrm{x}$ \\
\hline $\begin{array}{l}\text { Conjunction production: later-developing } \\
\text { conjunctions }\end{array}$ & $\sqrt{ }$ & $\sqrt{ }$ & $\sqrt{ }$ \\
\hline PASSIVES: total score & $\sqrt{ }$ & $\sqrt{ }$ & $\sqrt{ }$ \\
\hline Passive comprehension: reversible passives & $\sqrt{ }$ & $\sqrt{ }$ & $\sqrt{ }$ \\
\hline Passive comprehension: agentless passives & $\mathrm{x}$ & $\mathrm{x}$ & $\mathrm{x}$ \\
\hline Passive comprehension: agentive passives & $\mathrm{x}$ & $\mathrm{x}$ & $\mathrm{x}$ \\
\hline Total passive comprehension score & $\sqrt{ }$ & $\sqrt{ }$ & $\sqrt{ }$ \\
\hline Passive production: reversible passives & $\sqrt{ }$ & $\sqrt{ }$ & $\sqrt{ }$ \\
\hline $\begin{array}{l}\text { Passive production: agentive and agentless } \\
\text { passives }\end{array}$ & $\sqrt{ }$ & $\sqrt{ }$ & $\sqrt{ }$ \\
\hline Total passive production score & $\sqrt{ }$ & $\sqrt{ }$ & $\sqrt{ }$ \\
\hline WH QUESTIONS: total score & $\sqrt{ }$ & $\sqrt{ }$ & $\sqrt{ }$ \\
\hline $\begin{array}{l}\text { Wh question comprehension: conjoined } \\
\text { questions }\end{array}$ & $\sqrt{ }$ & $\sqrt{ }$ & $\sqrt{ }$ \\
\hline $\begin{array}{l}\text { Wh question comprehension: paired } \\
\text { exhaustive questions }\end{array}$ & $\sqrt{ }$ & $\sqrt{ }$ & $\sqrt{ }$ \\
\hline $\begin{array}{l}\text { Wh question comprehension: barrier } \\
\text { questions }\end{array}$ & $\sqrt{ }$ & $\sqrt{ }$ & $\sqrt{ }$ \\
\hline
\end{tabular}

\section{Discussion}

The research question posed in the present study concerns the effect of SES on the language skills of early school-aged children in New Zealand. The participants' scores on the normed language measures (PPVT-4 and CELF-4) show performance within the expected age norms across age and decile ranges, suggesting that neither the high- nor the low-decile participants ought to be considered part of the population at risk for academic failure and literacy acquisition problems. However, the language scores of the low-decile participants consistently fell significantly below those of their high-decile counterparts, raising a red flag in terms of both 
literacy skills and the ability to engage optimally in social and educational practices requiring complex language skills. In this section, we discuss the findings of the unnormed language measures $(R E A L t)$ in terms of the expected performance of children aged 5 to 7 years for each structure tested in the present study. These expectations are based on the literature regarding language development in typically-developing children. ${ }^{2}$

Little has been published on the development of comprehension and production of articles among typically-developing children, but the available literature does indicate that typicallydeveloping English-speaking children start using articles at the onset of the multi-word stage (Abu-Akel, Bailey and Thum 2004:419). Despite general vs. specific and part vs. whole distinctions possibly resulting in incorrect use of articles (but not in omission of articles after age 36 months; cf. Abu-Akel et al. 2004:420), it seems reasonable to expect children to have an established article system by school entry at 5 years. In terms of the comprehension of articles, this appeared to be the case for the high-decile participants but not for the low-decile participants. The high-decile group achieved high scores at 5 years, which did not improve significantly with an increase in age to 7 years. In contrast, the low-decile group had significantly lower scores than the high-decile group at 5 years, and these only improved significantly at 7 years, reaching the level of those of the high-decile group. With regard to article production, the high- and low-decile groups had similarly low scores at 5 years, thus appearing to lack the expected established article system at school entry, but whereas the highdecile group continued to improve significantly with an increase in age to 7 years, the lowdecile group's scores remained unchanged from 5 to 7 years. The findings on the comprehension and production of articles may suggest that the high-decile participants were sufficiently exposed during their preschool years to the type of language input necessary to develop comprehension of articles and their distinctions, whereas the low-decile participants were not. It may be that the low-decile children from backgrounds with less or poorer linguistic input require a long period of exposure to such input in the classroom to trigger the development of article comprehension and production.

Turning to the findings on binding, Binding Principle A (that reflexive pronouns must be bound in their local domain) is acquired relatively early by English-speaking children (Marinis and Chondrogianni 2011:203-204). Principle B (that non-reflexive pronouns may not be bound in their local domain but must refer to an outside determiner phrase), by contrast, is mastered somewhat later. In Deutsch, Koster and Koster's (1986) study, typically-developing 6-yearolds still made errors in identifying the referent of non-reflexive pronouns. These children generally performed around chance level, suggesting that they did not have a strong preference for either of the two interpretations. De Villiers, Cahillane and Altreuer (2006) found that typically-developing children's comprehension of binding relationships decreased if the noun is preceded by a quantifier like every (as in Here is Big Bird and all the bears. Every bear washes him/himself). In the De Villiers et al. (2006) study, children as old as 7 years still had problems with comprehension and production tasks targeting binding, and had more difficulty with comprehension than with production tasks, probably because a degree of avoidance is possible in production tasks but not in comprehension tasks. For example, in the production

\footnotetext{
2 There is limited literature available on the development of English by New Zealand children, thus we draw on studies published on other varieties of English, and, in some cases, on other West Germanic languages. We acknowledge that there might be different developmental paths across different varieties of English, and any generalisations should thus be interpreted with caution. Also, in order to keep the discussion succinct, we refer here to only a small number of the studies available on the acquisition of each structure.
} 
task, a child can complete a stimulus like Here is Baby Bear and here is Daddy Bear. Baby Bear is washing ... with Baby Bear, rather than with himself. Based on this literature, the prediction in the present study was that both high- and low-decile groups might achieve low scores for binding comprehension and production at 6 years, with somewhat higher scores at 7 years. For comprehension, this was the case to some extent. There was indeed an improvement in scores with an increase in age, but both groups already achieved good scores at 5 years, and scored even higher at 6 years (not only at 7 years, as had been expected), after which the scores stabilised. Note, however, that the scores of the low-decile group were consistently significantly lower than those of the high-decile group. A similar trajectory was seen for binding production, where the low-decile group again consistently scored lower than the high-decile group, albeit not significantly so.

Concerning conjunctions, observational studies have shown that young children can set two sentences against each other without a conjunction or other linguistic element to indicate how they are connected (cf., amongst others, Bloom, Lahey, Hood, Lifter and Fliess 1980; Eisenberg 1980). As Diessel (2004:150) states, "This has been taken as evidence for the hypothesis that the child's cognitive development precedes the linguistic development of conjoined clauses: Children seem to learn temporal, causal, and conditional relationships before they are able to indicate these relationships by temporal, causal, and conditional conjunctions." When children do begin to use conjunctions, there are clearly earlier-developing and later-developing conjunctions, although the exact ages concerned are not always as clear. The discussion below draws from results published by Clancy, Jacobsen and Silva (1976), De Houwer and Gillis (1998), Diessel (2004) and Southwood, Carinus and Engelbrecht (2010). In general, it appears that the developmental sequence of conjunctions is determined by the complexity of the relationship expressed by the conjunction. The group of very-early-appearing conjunctions includes and, because, so, but and or. They are established between 3 years and 4 years 6 months, but children then often take still longer to fully comprehend the cause-effect meaning of because. Other conjunctions which also develop early, but not as early, are if (from about 4 years to 4 years 6 months), when, until, after, before, while and since. Conjunctions which develop even later include certain temporal (as soon as, whenever), conditional (unless), and concession (although) conjunctions. Based on the available literature, all participant groups in the present study were expected to have mastered earlier-developing conjunctions, and all but the 5-year-olds were expected to have mastered later-developing conjunctions. The findings did not support this expectation. Firstly, at 5 years, neither group fared well with the REALt conjunction items, with the low-decile group achieving significantly lower scores than the highdecile group. Furthermore, the high-decile group's scores did not improve with an increase in age, whereas those of the low-decile group did improve from 5 to 6 years but not from 6 to 7 years. At 6 and 7 years, there were no statistically significant differences between the two decile groups. These findings suggest that, as was the case for article comprehension, low-decile children catch up with their high-decile peers in terms of earlier-developing conjunctions sometime after entering school. Secondly, both decile groups achieved low scores on laterdeveloping conjunctions at age 5 years (as was expected), but these scores did not change significantly with an increase in age. Once again, however, the low-decile group obtained significantly lower scores than the high-decile group.

With regard to passive constructions, typically-developing children acquire short passives before full passives (Horgan 1978), and already understand action passives at about 4 years of age (Maratsos, Fox and Challdey 1985:172). Other types of passive constructions, however, 
develop rather later. Horgan (1978) studied spontaneous samples of 234 children aged 2 to 13 years for three types of passives: reversible passives (e.g. The dog is chased by the cat-The cat is chased by the dog); instrumental non-reversible passives (e.g. The window was broken with a bat); and agentive non-reversible passives (e.g. The window was broken by the boys). The latter type of passive appeared only after 9 years of age, and no child younger than 11 years produced both reversible and non-reversible passives. Passive constructions can thus be labelled as decidedly late-developing. Based on this literature, the 5-year-olds in the present study were expected to achieve relatively low scores for passive comprehension and production, which would then improve with an increase in age. The findings for comprehension bore out this expectation for both decile groups, with the low-decile group consistently scoring significantly lower than the high-decile group. For production, the low-decile scores were also consistently significantly lower than the high-decile scores, but there were also other differences between the decile groups: Whereas the high-decile scores at 5 years were already high and improved slightly with an increase in age, the low-decile scores at 5 years were low, improved greatly from 5 to 6 years, and improved slightly further from 6 to 7 years. Furthermore, the low-decile scores at 7 years remained lower than the high-decile scores at 5 years. For passive production, the two decile groups thus displayed different trajectories. The data suggest that the low-decile group, but not the high-decile group, entered school having had insufficient exposure to passive constructions in their input thus far, and that passive production abilities may have been triggered by the input during their early school years, as suggested above for article comprehension and the production of earlier-developing conjunctions. In the case of passives, however, the low-decile 7-year-olds still lagged behind their 5-year-old highdecile counterparts in terms of passive production. As passives occur relatively frequently in textbooks and other print media, this raises a red flag regarding the ability of the low-decile participants to comprehend textbook and related classroom discourse in the manner expected of them.

Finally, concerning $\boldsymbol{w h}$ questions, typically developing children master single wh questions relatively early. Stromswold (1995) studied who, what and which questions in the language of 12 English-speaking children aged 1 to 6 years and found that object questions were acquired around 2 years 3 months and subject questions around 2 years 5 months. Some more complex object questions appeared around 2 years 10 months. The findings of Roeper (2004) show a strong developmental trend for the comprehension of more complex paired exhaustive and barrier questions, with mastery only around 4 to 7 years. As the present study focused on comprehension of complex question types, the expectation was for participants to achieve low scores at 5 years and to improve with an increase in age, but not yet exhibit mastery at 7 years. The findings showed that this was indeed the case for conjoined and paired exhaustive questions, but the participants' comprehension of barrier questions did not improve with an increase in age. In all cases, the low-decile group achieved lower scores than the high-decile group.

In summary, at school entry (at age 5 years), the participants from low-SE backgrounds in the current study lagged behind their counterparts from high-SE backgrounds in terms of the comprehension of articles, binding relations, passive constructions and wh questions, and in terms of the production of earlier- as well as later-developing conjunctions and passive constructions. Indeed, in the case of passives, the low-decile group score at 7 years was similar to that of the high-decile group at 5 years. Furthermore, whereas the high-decile group improved in terms of article production with an increase in age, the low-decile group did not. Thus, in this 
study, even 7-year-old children from low-SE backgrounds demonstrated less-developed language skills than their peers from high-SE backgrounds. In this regard, note that Van Hees (2011) reported that interaction and discourse in low-SE classrooms in New Zealand did not provide optimal conditions for language acquisition. These findings raise concerns about the ability of children from low-SE backgrounds to fully engage in classroom discourse. To the extent that mastery of complex language skills is essential for children to benefit maximally from classroom activities and teacher input in achieving academic success (cf. Stevenson and Newman 1986; Storch and Whitehurst 2002; Craig, Connor and Washington 2003; O'Neil, Pearce and Pick 2004; Magnuson and Ducan 2006; Pungello, Irukha, Dotterer, Mills-Koonce and Reznick 2009), the findings suggest that the language skills of young school-going children from low-SE backgrounds warrant further attention.

The low-decile children in this study were attending schools that received extra government funding toward educational resources, but it appears that this provision per se does not result in language skills on par with those of children from higher-decile schools. Whereas prolonged exposure of children from low-SE backgrounds to language input in the everyday classroom might aid the acquisition of certain language structures, they may remain without the language skills required for optimal learning during this prolonged period. A more proactive approach to developing the complex language skills of children from low-SE backgrounds is perhaps required, beginning with the recognition of this group of children as a population at risk for academic failure and literacy acquisition problems related to poor language skills and thus in need of targeted language stimulation.

\section{Conclusion}

From the findings reported above, it appears that the receptive and expressive language skills of young school-aged children in New Zealand do vary across the SE range. Although such variation has been reported for other contexts, it was not expected to occur in the New Zealand context, for two reasons.

Firstly, New Zealand is a well-resourced country with a Human Development Index ${ }^{3}$ ranking of 7 (United Nations 2015b), which spends $7.24 \%$ of its gross domestic product on education. Ninety-three percent of New Zealand children attend a preschool facility, and the average educator:learner ratio in schools is 1:15 (United Nations 2015a). ${ }^{4}$ One would expect that the relatively small number of New Zealand children from low-SE backgrounds would have a good chance of being adequately assisted so as to not lag behind their more affluent peers.

Secondly, as discussed above, the New Zealand Ministry of Education provides extra funding to schools attended by large numbers of children from low-SE backgrounds in order to "enable [these schools] to overcome the barriers to learning faced by students from lower socioeconomic communities" (New Zealand Ministry of Education 2015c). Despite these efforts, the language skills of early school-age children in New Zealand appear to be similarly vulnerable

\footnotetext{
${ }^{3}$ The United Nations (2015a) states that "the Human Development Index ... is a summary measure of average achievement in key dimensions of human development: a long and healthy life, being knowledgeable and have [sic] a decent standard of living".

${ }^{4}$ For the sake of comparison: South Africa has a Human Development Index ranking of 118, spends 5.98\% of its gross domestic product on education, has $77 \%$ of its children attending a preschool facility, and has an average educator:learner ratio in schools of 1:30.
} 
to the effects of SE background as those of children from other countries, with the skills of children from low-SE backgrounds being less well-developed than those of their more affluent peers.

As stated above, schools in New Zealand are specifically divided into deciles in an effort to ensure that those with higher proportions of children from low-SE communities receive the resources required to assist their students to fulfil their academic potential (New Zealand Ministry of Education 2015a). The present findings suggest that, even with such assistance, young children in low-decile schools are not performing on par with those in high-decile schools in terms of language skills. Established preschool programmes are in place in New Zealand, with government assistance allowing children from low-SE communities to attend, but it may be that the language skills curricula within such preschool programmes ought to be reconsidered in order for children from low-SE communities to receive increased exposure to those language structures which have been shown to be important for academic success.

Whereas the home and preschool language environments of New Zealand children from lowSE backgrounds do not currently in all cases lead to the mastery of certain language structures, it appears from the results of this study that knowledge of these structures continues to develop after entering school. This continued development could be due to one or a combination of factors, such as the quality of language input received in the classroom, more varied verbal interaction with a greater number of conversational partners after entering school or general maturation. Despite the observed increase in some language skills, the 7-year-old children from low-SE backgrounds in this study remained generally outperformed by their peers from highSE backgrounds. This could in part be due to the persistent nature of the differences between the quality and quantity of input received by children from low-SE households and that received by their middle-class peers, which leads to a gap between children from low- and high-SE families that tends to widen over time (cf. Hart and Risley 2003). Whereas certain measures can be taken to avoid this widening effect, narrowing the gap seems difficult (e.g. preschool attendance appears to prevent the widening of the gap in vocabulary knowledge between children of higher- and lower-educated parents, but does not allow children of lower-educated parents to catch up with their peers with higher-educated parents; cf. Becker 2011:79-82). These measures include preschool programmes deliberately focusing on language, storybook reading, alphabetic skills and/or writing (cf. Aram and Biron 2004 for a report on successful programmes of this nature; also cf. Robbins and Ehri 1994); diversifying classrooms so that children who enter the school year with poor language skills can benefit from being in prolonged close contact with classmates who have well-developed language skills (cf. Justice, Petscher, Schatschneider and Mashburn 2011 for a report on such peer effects) and deliberate exposure to dialogic reading activities (cf. Klop 2003 for a report of the success of even short-term engagement in such activities).

The study reported here has several limitations, including small sample sizes and geographical restriction. Ideally, the study of the effects of SES on children's language skills should be expanded to other areas of New Zealand and should cover a larger age range. The latter would allow one to ascertain whether the trajectory of children from low-SE backgrounds matches that of their middle-class peers, but is merely delayed. In this regard, the present findings indicated that several language structures remained un-mastered by 7 -year-old children from low-SE backgrounds, and the question remains whether these skills are indeed mastered later, sometime after 7 years. Given the well-documented correlation between language skills, 
academic performance and literacy acquisition (e.g. Klop and Tuomi 2007; Hayiou-Thomas, Harlaar and Dales 2010), the findings of the current study indicate that merely increasing the funding offered to schools in low-SE areas does not necessarily successfully address children's language development needs. Because of the link between language skills, academic status and literacy acquisition, more creative initiatives may be called for if these children are to cease being at-risk for later literacy acquisition and academic performance problems.

\section{Acknowledgments}

The authors would like to thank Gia Kuek and Amanda Lee for their assistance in data collection. The data on which this article is based were collected with the financial support of the New Zealand Institute of Language, Brain and Behaviour, Canterbury University.

\section{References}

Abu-Akel, A., A.L. Bailey and Y.M. Thum. 2004. Describing the acquisition of determiners in English: A growth modeling approach. Journal of Psycholinguistic Research 33(5): 407-424.

Aram, D. and S. Biron. 2004. Joint storybook reading and joint writing interventions among low SES preschoolers: Differential contributions to early literacy. Early Childhood Research Quarterly 19(4): 588-610.

Aram, D.M. and J.E. Nation. 1980. Preschool language disorders and subsequent language and academic difficulties. Journal of Communication Disorders 13: 159-170.

Arriaga, R.J., L. Fenson, T. Cronan and S.J. Pethick. 1998. Scores on the MacArthur Communicative Development. Inventory of children from low- and middle-income families. Applied Psycholinguistics 19: 209-223.

Becker, B. 2011. Social disparities in children's vocabulary in early childhood. Does pre-school education help to close the gap? The British Journal of Sociology 62(1): 69-88.

Bloom, L., M. Lahey, L. Hood, K. Lifter and K. Fliess. 1980. Complex sentences: Acquisition of syntactic connectives and the semantic relations they encode. Journal of Child Language 7: 235-261.

Cartmill, E.A., B.F. Armstrong, L.R. Gleitman, S. Goldin-Meadow, T.N. Medina and J.C. Trueswell. 2013. Quality of early parent input predicts child vocabulary 3 years later. Proceedings of the National Academy of Sciences 110(28): 11278-11283.

Chomsky, N. 1981. Lectures on government and binding. Dordrecht: Foris.

Clancy, P., T. Jacobsen and M. Silva. 1976. The acquisition of conjunction: A crosslinguistic study. Stanford Papers and Reports on Child Language 12: 71-80.

Conti-Ramsden, G., E. Knox, N. Botting and Z. Simkin. 2002. Educational placements and National Curriculum Key Stage 2 test outcomes of children with a history of specific language impairment. British Journal of Special Education 29: 76-82. 
Craig, H.K., C.M. Connor and J.A. Washington. 2003. Early positive predictors of later reading comprehension for African American students: A preliminary investigation. Language, Speech, and Hearing Services in Schools 34: 31-43.

De Houwer, A. and S. Gillis. 1998. The acquisition of Dutch. Amsterdam \& Philadelphia: John Benjamins.

Deutsch, W., C. Koster and J. Koster. 1986. Children's errors in understanding anaphora. Linguistics and Philosophy 24: 203-225.

De Villiers, J., J. Cahillane and E. Altreuer. 2006. What can production reveal about Principle B? University of Connecticut Occasional Papers in Linguistics 4: 89-100.

Diessel, H. 2004. The acquisition of complex sentences. Cambridge, UK: Cambridge University Press.

Duncan, G.J., W.J. Yeung, J. Brooks-Gunn and J.R. Smith. 1998. How much does childhood poverty affect the life chances of children? American Sociological Review 63(3): 406-423.

Dunn, L.M. and D.M. Dunn. 2007. Peabody Picture Vocabulary Test - Fourth edition. Minneapolis: Pearson Assessments.

Dunn, L.M., D.M. Dunn, C. Whetton and J. Burley. 1997. The British Picture Vocabulary Scale. London: NFER-Nelson.

Eisenberg, A.R. 1980. A syntactic, semantic and pragmatic analysis of conjunctions. Papers and Reports on Child Language Development 19: 70-78.

Feldman, H.M., C.A. Dollaghan, T.F. Campbell, M. Kurs-Lasky, J.E. Janosky and J.L. Paradise. 2000. Measurement properties of the MacArthur Communicative Development Inventory at ages one and two years. Child Development 71: 310-322.

Hackman, D.A. and M.J. Farah. 2009. Socioeconomic status and the developing brain. Trends in Cognitive Sciences 13(2): 65-73.

Hart, B. and T.R. Risley. 1992. American parenting of language-learning children: Persisting differences in family child interactions observed in natural home environments. Developmental Psychology 28(6): 1096-1105.

Hart, B. and T.R. Risley. 1995. Meaningful differences in the everyday experiences of young American children. Baltimore, MD: Brookes Publishing.

Hart, B. and T.R. Risley. 2003. The early catastrophe: The 30 million word gap by age 3. American Educator 27(1): 4-9.

Hayiou-Thomas, M., N. Harlaar and P. Dales. 2010. Preschool speech, language skills, and reading at 7, 9 and 10 years: Etiology of the relationship. Journal of Speech Language and Hearing Research 53(2): 311-332. 
Heath, S B. 1982. Questioning at home and at school: A comparative study. In G. Spindler (ed.) Doing the ethnography of schooling: Educational anthropology in action. New York: Holt, Rinehart \& Winston. pp. 102-131.

Heath, S.B. 1983. Ways with words: Language, life, and work in communities and classrooms. Cambridge: Cambridge University Press.

Hoff, E. 2003. The specificity of environmental influence: Socioeconomic status affects early vocabulary development via maternal speech. Child Development 74(5): 1368-1378.

Hoff-Ginsberg, E. 1991. Mother-child conversation in different social classes and communicative settings. Child Development 62(4): 782-796.

Horgan, D. 1978. The development of the full passive. Journal of Child Language 5(5): 65-80.

Huttenlocher, J., M. Vasilyeva, E. Cymerman and S.C. Levine. 2002. Language input at home and at school: Relation to syntax. Cognitive Psychology 45(3): 337-374.

Justice, L.M., Y. Petscher, C. Schatschneider and A. Mashburn. 2011. Peer effects in preschool classrooms: Is children's language growth associated with their classmates' skills? Child Development 82(6): 1768-1777.

Klop, D. 2003. Die verhoging van voorskoolse kinders se sintaktiese kompleksiteit deur blootstelling aan dialogiese lees. Stellenbosch Papers in Linguistics Plus 32: 157-171.

Klop, D. and S.K. Tuomi. 2007. The persistence of language disorders in a group of disadvantaged Grade 3 learners. The South African Journal of Communication Disorders 54: 59-66.

Magnuson, K.A. and G.J. Ducan. 2006. The role of family socioeconomic resources in the Black-White test score gap among children. Developmental Review 26: 365-399.

Maratsos, M., D. Fox and M.A. Challdey. 1985. Semantic restrictions on children's passives. Cognition 19: 167-191.

Marinis, T. and V. Chondrogianni. 2011. Comprehension of reflexives and pronouns in sequential bilingual children: Do they pattern similarly to L1 children, L2 adults, or children with specific language impairment? Journal of Neurolinguistics 24: 202-212.

New Zealand Ministry of Education. 2015a. School decile ratings. Available online: http://www.minedu.govt.nz/parents/allages/educationinnz/schoolsinnewzealand/schooldeciler atings.aspx (Accessed 7 April 2015).

New Zealand Ministry of Education. 2015b. Deciles - questions and answers. Available online: http://www.education.govt.nz/school/running-a-school/resourcing/operational-

funding/school-decile-ratings/ (Accessed 18 November 2015). 
New Zealand Ministry of Education. 2015c. Deciles - questions and answers. Available online: http://www.education.govt.nz/school/running-a-school/resourcing/operationalfunding/deciles/review-of-deciles-general-information/ (Accessed 20 July 2015).

O’Neil, D.K., M.J. Pearce and J.L. Pick. 2004. Preschool children's narratives and performance on the Peabody Individualised Achievement Test-Revised: Evidence of a relation between early narrative and later mathematical ability. First Language 24: 149-183.

Pungello, E.P., I.U. Iruka, A.M. Dotterer, R. Mills-Koonce and J.S. Reznick. 2009. The effects of socioeconomic status, race, and parenting on language development in early childhood. Developmental Psychology 45(2): 544-557.

Raizada, R.D.S., T.L. Richards, A. Meltzoff and P.K. Kuhl. 2008. Socioeconomic status predicts hemispheric specialisation of the left inferior frontal gyrus in young children. NeuroImage 40: 1392-1401.

Rescorla, L. 1989. The Language Development Survey: A screening tool for delayed language in toddlers. Journal of Speech and Hearing Disorders 54: 587-599.

Rescorla, L. and A. Alley. 2001. Validation of the Language Development Survey (LDS): A parent report tool for identifying language delay in toddlers. Journal of Speech, Language, and Hearing Research 44: 434-445.

Robbins, C. and L.C. Ehri. 1994. Reading storybooks to kindergartners helps them learn new vocabulary words. Journal of Educational Psychology 86(1): 54-64.

Roeper, T. 2004. Diagnosing language variations: Underlying principles for syntactic assessment. Seminars in Speech and Language 25(1): 41-55.

Roeper, T. 2007. The prism of grammar. Cambridge, Massachusetts: MIT Press.

Semel, E., E.H. Wiig and W.A. Secord. 2006. Clinical Evaluation of Language Fundamentals. Fourth edition (Australian). Marrickville: Harcourt Assessment.

Seymour, H.N., T. Roeper and J. de Villiers. 2005. Diagnostic Evaluation of Language Variation. Examiner's manual. San Antonio: Harcourt Assessment.

Southwood, F., M. Carinus and S. Engelbrecht. 2010. The use of discourse markers by Afrikaans-speaking preschoolers with and without specific language impairment. Stellenbosch Papers in Linguistics Plus 40: 79-94.

Southwood, F. and O. van Dulm. 2012. Receptive and expressive activities in language therapy. Johannesburg: JvR Psychometrics.

Stevenson, H.W. and R.S. Newman. 1986. Long-term prediction of achievement and attitudes in mathematics and reading. Child Development 57: 646-659. 
Storch, S.A. and G.J. Whitehurst. 2002. Oral language and code-related precursors to reading: Evidence from longitudinal structural model. Developmental Psychology 38: 934-947.

Stromswold, K. 1995. The acquisition of subject and object wh-questions. Language Acquisition 4(1-2): 5-48.

The World Bank Group. 2015. New Zealand. Available online: http://data.worldbank.org/country/new-zealand (Accessed 15 November 2016).

Tough, J. 1982. Language, poverty, and disadvantage in school. In L. Feagans and D.C. Farran (eds.) The language of children reared in poverty. New York, etc.: Academic Press. pp. 3-18.

United Nations. 2015a. United Nations Development Programme - Human development reports: New Zealand. Available online: http://hdr.undp.org/en/countries/profiles/NZL (Accessed 20 July 2015).

United Nations. 2015b. United Nations Development Programme - Human development reports: Human Development Index (HDI). Available online: http://hdr.undp.org/en/content/human-development-index-hdi (Accessed 20 July 2015).

Van Hees, J. (n.d.) Expanding expression - expanding cognition: An investigation. Available online: http://www.cognitioneducationtrust.org/wp-content/uploads/2013/09/report_ cognition_institute_jannie_van_hees.pdf (Accessed 26 November 2015).

Van Hees, J.A.G. 2011. Oral expression of five and six year olds in low socioeconomic schools (Doctoral dissertation). Available online: https://researchspace.auckland.ac.nz/handle/2292/9792 (Accessed 27 March 2015).

Walker, D., C. Greenwood, B. Hart and J. Carta. 1994. Prediction of school outcomes based on early language production and socioeconomic factors. Child Development 65: 606-621.

Whitehurst, G.J. 1997. Language processes in context: Language learning in children reared in poverty. In L.B. Adamson and M.A. Romski (eds.) Communication and Language Acquisition: Discoveries from Atypical Development. Baltimore: MD Brookes. pp. 233-265.

Yeung, W.J., M.R. Linver and J. Brooks-Gunn. 2002. How money matters for young children's development: Parental investment and family progresses. Child Development 73(6): 18611879. 